\title{
Immunomodulatory effects of some Namibian plants traditionally used for treating inflammatory diseases
}

\author{
C.I. Du Preez ${ }^{\mathrm{a}, *}$, C. Gründemann ${ }^{\mathrm{c}}$, J.K. Reinhardt ${ }^{\mathrm{c}}$, D.R. Mumbengegwi ${ }^{\mathrm{a}}$, R. Huber ${ }^{\mathrm{b}}$ \\ ${ }^{\text {a }}$ Programme for Traditional Medicine and Drug Discovery, Multidisciplinary Research Centre, University of Namibia, 340 Mandume Ndemufayo Avenue, Pioneers Park, \\ Windhoek, Namibia \\ ${ }^{\mathrm{b}}$ Center for Complementary Medicine, Institute for Infection Prevention and Hospital Epidemiology, University of Freiburg, Faculty of Medicine, Breisacherstr. 115B, \\ 79106, Freiburg, Germany \\ ${ }^{\mathrm{c}}$ Department of Pharmaceutical Sciences, University of Basel, Klingelbergstrasse 50, CH-4056 Basel, Switzerland
}

\section{A R T I C L E I N F O}

\section{Keywords:}

Immunomodulatory

Lymphocytes

Inflammation

Traditional medicine

Namibia

Acanthosicyos naudinianus

Gomphocarpus fruticosus

Cryptolepis decidua

\begin{abstract}
A B S T R A C T
Ethnopharmacological relevance: Acanthosicyos naudininus, Gomphocarpus fruticosus, and Cryptolepis decidua are, according to the knowledge of traditional healers, used in Namibia to treat inflammatory disorders such as pain, fever and skin rashes.

Aim of the study: The present study was conducted to evaluate the immunomodulatory effects and the possible underlying mechanisms of action of the plant extracts on peripheral blood mononuclear cells (PBMCs) such as T-lymphocytes.

Materials and methods: Methanolic and EtOAc extracts of A. naudinianus, G. fruticosus and C. decidua were analysed for their immunomodulatory potential. PBMCs were isolated from the blood of healthy donors and incubated with the plant extracts at concentrations $100,30,10,3,1$ and $0.3 \mu \mathrm{g} / \mathrm{mL}$. Effects on proliferation and viability of activated human lymphocytes were assessed in comparison to ciclosporin A by flow cytometry using carboxyfluorescein succinimidyl ester (CFSE) and WST-1 assay. Flow cytometry by annexin V/propidium iodide (PI) staining was performed to investigate the necrotic/apoptotic effect of the plant extracts on mitogen-activated human lymphocytes. In addition, analysis of the influence of plant extracts on the regulatory mechanisms of T-lymphocytes was performed using activation marker and cytokine production assays. An HPLC-PDA-ELSDESIMS profile was recorded for each of the extracts.

Results: T-lymphocyte proliferation was inhibited in a dose-dependent manner by the extracts of $A$. naudinianus, G. fruticosus, and C. decidua in concentrations not causing apoptosis or necrosis. This effect was mediated by inhibition of lymphocyte activation, specifically the suppression of CD25 and CD69 surface receptor expression. Moreover, the extracts suppressed effector functions, as indicated by reduced production of IFN- $\gamma$ and IL- 2 . Based on the HPLC profile, possible responsible compound classes could be identified for the extracts of A. naudinianus (cucurbitacins) and C. decidua (indole alkaloids), but not for G. fruticosus.

Conclusions: The data show that the extracts of A. naudinianus, G. fruticosus and $C$. decidua have in vitro immunomodulatory activity and they interfere with the function of immunocompetent cells, suggesting an antiinflammatory mode-of-action. The present chemical determination and pattern recognition results explain the therapeutic potency. However, further studies to investigate the therapeutic potential of the plants in inflammatory disorders should be done.
\end{abstract}

\section{Introduction}

The immune system is responsible for overall human health, protecting the body from disease. However, this same immune system, if unstable, can cause tissue damage and pathology (Chen et al., 2017). Chronic inflammatory responses, which are part of the body's defence response, are a result of such a process. Long-term exposure to low levels of inflammation, can cause diseases such as diabetes, cardiovascular disorders, arthritis, joint diseases, allergies (Pahwa et al., 2019), cancer, respiratory diseases, mental disorders, and autoimmune disorders (AID) (Bosma-den Boer et al., 2012). Moreover, autoimmune disorders, which are characterized by an overly sensitive immune

\footnotetext{
* Corresponding author. Private bag 13301, Windhoek, Namibia.

E-mail addresses: idupreez@unam.na (C.I. Du Preez), carsten.gruendemann@uniklinik-freiburg.de (C. Gründemann), jakob.reinhardt@unibas.ch (J.K. Reinhardt), dmumbengegwi@unam.na (D.R. Mumbengegwi), roman.huber@uniklinik-freiburg.de (R. Huber).
} 
system attacking healthy tissues (Pahwa et al., 2019), can give rise to diseases such as rheumatoid arthritis, systemic lupus erythematosus (SLE), multiple sclerosis, type 1 diabetes mellitus, and psoriasis. Generally, these conditions are debilitating and can affect quality of life. Importantly, these diseases are on an increase worldwide and are responsible for a high death toll (Pahwa et al., 2019); therefore regulating the immune system is essential in combatting these diseases.

Besides the limited availability of anti-inflammatory drugs, which have been shown to have numerous side effects (Oguntibeju, 2018), a number of herbal treatments are available (Ko et al., 2014) and are progressively used in the treatment of many chronic illnesses (Lull et al., 2005; Du Preez et al., 2011; Du Preez, 2012; Ghasemian et al., 2016). However, a lack of evidence on the efficacy for the herbal remedies remains a barrier. Research on ethnomedicines could contribute to a cost-effective management of inflammatory disorders, improving the quality of life of patients, and in so doing managing these disorders.

Namibia, a country in southwest Africa, has a strong history on use of traditional herbal medicines, for many of them scientific studies have not been conducted. There are about 2400 traditional practitioners in Namibia and numerous plant species are used for medicinal purposes (Von Koenen, 2007; Cheikhyoussef et al., 2011; Brumbaugh, 2015). There is a heavy reliance on traditional medicine in both rural and urban areas emphasizing that people are knowledgeable about the names and uses of medicinal plants in addressing their health care needs. As such, three plants were selected following field excursions in the Hardap region in southern Namibia. These plants treat a wide array of diseases including skin disorders which are inflammatory responses.

Leaves from Gomphocarpus fruticosus have been used for treating febrile distemper, tuberculosis (TB) and gastro-intestinal complaints in Namibia, while the roots have been used for diabetes and the latex for warts as reported by Von Koenen (2007). Schmelzer et al. (2013) reported similar uses with different plant parts; for instance the whole plant $G$. fruticosus is used to treat illnesses such as coughing, diabetes, tumors, and skin disorders including scabies and itchy skin. A tea prepared using the root is drunk daily to treat diabetes and the San people use the latex as an arrow poison ingredient. The leaves are also used to rub the body in order to treat skin cancer in southern parts of Namibia (Maguraushe, 2017). A study by Abe et al. (1994) reported that $G$. fruticosus contains steroidal glycosides and, in the latex, cysteine peptidases (Trejo et al., 2009), whilst Ndhlala et al. (2011) showed the watery extract of the plant to be nonmutagenic using an Ames test. Cryptolepis decidua roots, on the other hand are used as a remedy by the Damara people for stomach ache, intestinal and liver pain, constipation, vomiting; whereas the Nama and Himba use the root decoction for gastrointestinal problems like diarrhoea. The roots are also used for skin rashes attributed to venereal diseases and afterbirth cleansing of the uterus. The Topnaar community, other than for constipation and stomach ache, use the roots to treat menstrual pain, stomach ache, fever, common cold and TB symptoms (Schmelzer et al., 2013).

Acanthosicyos naudinianus, according to Stuurmann (2016), is used to manage cancer by the Nama people. It is used to treat fever, headaches, diarrhoea, abdominal pain, cough, skin lesions, inflammation and sicknesses that are associated with HIV. This plant is also believed to help for treatment of gonorrhoea, body sores, fungal infections of the skin and skin rashes (Chinsembu et al., 2014). Furthermore, chemical compounds known as cucurbitacins, which are common in Cucurbitaceae and various other plant species, are found to be cytotoxic (including anticancer activity) and have anti-inflammatory and analgesic properties (Grubben, 2004). In a recent ethnopharmacological study, the aqueous root extract exhibited activity against MCF7, UACC62 and TK10 cancer cells with IC $_{50}$ values of $6.25 \mu \mathrm{g} / \mathrm{mL}, 16.41 \mu \mathrm{g} / \mathrm{mL}$ and $48.85 \mu \mathrm{g} / \mathrm{mL}$, respectively with moderate cytotoxic activity against normal fibroblast cells (Stuurmann, 2016). The ethanol root extract, however, exhibited low in vitro anticancer activity and weak cytotoxicity effects of $\mathrm{IC}_{50} 83.34 \mu \mathrm{g} / \mathrm{mL}$.

Plant extracts are complex mixtures of compounds (Li et al., 2011), the chemical profiles of plants are linked to the efficacy of plants as ethnomedicines (Arendt and Zannini, 2013; Diep et al., 2015; Huang et al., 2016; Kumar, 2019). A robust tool such as HPLC is needed to isolate and identify compounds (Bansal et al., 2014). This tool is not only important in the quality control of existing herbal products both raw and finished (Belščak-Cvitanović et al., 2017; Thirumal and Laavu, 2017), but also for standardization of harvesting and extraction methods (Kunle et al., 2012). It can also be used in developing new drugs from traditional medicine (Sasidharan et al., 2010). The study aimed to evaluate the immunomodulatory properties for the abovementioned plants using lymphocytes which are essential in inflammatory responses, and when regulated, can prevent self-tissue or cell destruction (Camara et al., 2012). Using HPLC, we were able to identify possible compounds responsible for the therapeutic effects observed in this study.

\section{Methods and materials}

\subsection{Selection and collection of plants}

Traditional medicines based on plants endemic to Namibia were selected using an ethnopharmacolgical approach (Oliveira et al., 2011; Silva et al., 2013). Traditional healers from the Hardap region in Namibia were identified with the help of local contact persons and surveyed with a structured interview and the help of a translator. The interview comprised, amongst others, questions on which plants have been used for treating inflammatory conditions. Fresh plant material of Acanthosicyos naudinianus, Gomphocarpus fruticosus, and Cryptolepis decidua (foliage: $G$. fruticosus, tubers: $A$. naudinianus and roots: $C$. decidua) were collected in the Hardap region of Namibia (Fig. 1) beginning of the raining season in a sustainable manner to ensure the continued viability of those plant populations. The plant samples were placed in paper bags, properly labelled and transported to Windhoek in dry, cool, well-ventilated containers. In addition, a sample of each plant (25-40 cm long and up to $26 \mathrm{~cm}$ wide) was collected and preserved using a plant press for confirmation of the scientific nomenclature of the plants. This confirmation of identity was done by botanists of the National Botanical Research Institute (NBRI) of Namibia. Information on the respective family, local and English names, and voucher specimen numbers are shown in Table 1 . The names of the plants were verified with http://www.theplantlist.org indicating that they are all recognized names of species in the respective genera.

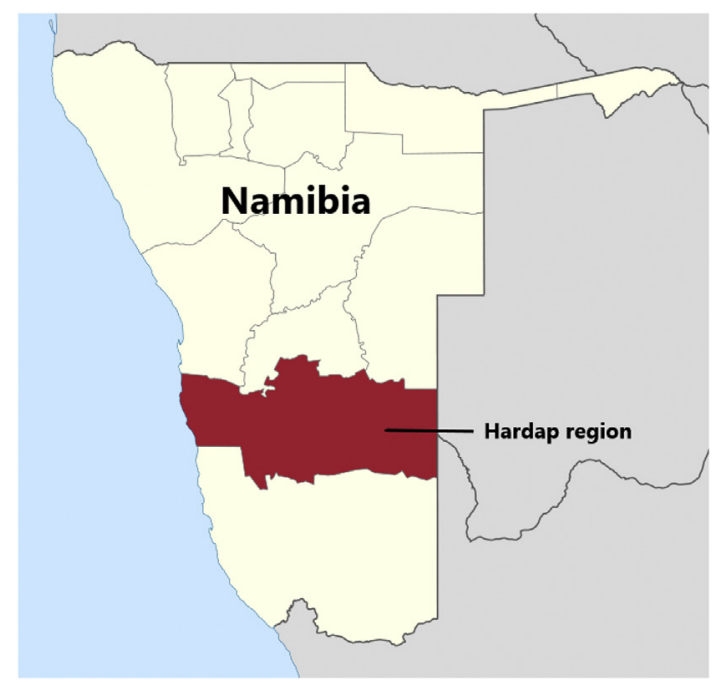

Fig. 1. Map of Namibia showing the Hardap region where plants were collected. 


\subsection{Extract preparation}

Maceration methods were used to prepare dry plant extracts. A sequential extraction of the same plant material with solvents of increasing polarity (EtOAc and $\mathrm{MeOH}$ ) was performed. Two cycles of extraction for each solvent were done to make the extraction as exhaustive as possible. For this, a weighed amount of dried plant material $(10 \mathrm{~g})$ was placed in an Erlenmeyer flask, suspended in $100 \mathrm{~mL}$ of solvent and stirred using an orbital shaker for $24 \mathrm{~h}$ at room temperature. Thereafter, gravity filtration was done using Grade 1 Whattman filter paper. The cycle was repeated for each solvent, and the extracts were dried on a rotary evaporator (water bath set at $40^{\circ} \mathrm{C}$ ) followed by a freeze-dryer under reduced pressure. The dry extracts were collected and stored in airtight cryovials at $-20^{\circ} \mathrm{C}$.

\subsection{Human peripheral blood mononuclear cells (PBMCs) isolation}

Peripheral blood mononuclear cells (PBMCs) or lymphocytes were isolated from the blood of healthy donors obtained from the Blood Transfusion Centre (University Medical Centre, Freiburg, Germany). In detail, the blood was centrifuged on a LymphoPrep ${ }^{\mathrm{TM}}$ gradient (density: $1.077 \mathrm{~g} / \mathrm{cm}^{3}, 20 \mathrm{~min}, 500 \times \mathrm{g}, 20^{\circ} \mathrm{C}$; Progen, Heidelberg, Germany). Cells were washed 3 times with Dulbecco phosphate buffered saline (PBS) $1 \mathrm{x}(\mathrm{CaCl})$. Thereafter, the cells were re-suspended in the growth medium consisting of RPMI-1640 1x (Gibco) supplemented with 10\% foetal calf serum (FCS), 1\% penicillin/streptomycin (Gibco), 1\% glutamine, and $0.025 \%$ of $\beta$-mercaptoethanol (complete medium). In the case of the CFSE assay, the cells were re-suspended in PBS. The cell viability as well as cell density were determined using the trypan blue exclusion test.

\subsection{Activation and treatment of lymphocytes}

Lymphocytes were stimulated with anti-human CD3 (clone HIT3a) and anti-human CD28 (clone 28.2) $\mathrm{mAbs}$ (each $100 \mathrm{ng} / \mathrm{mL}$; eBioscience, Frankfurt, Germany) $(1: 100 \mathrm{v} / \mathrm{v})$ as indicated by the presence of the medium, ciclosporine A (CsA; $5 \mu \mathrm{g} / \mathrm{mL}$; Sandimmun $50 \mathrm{mg} / \mathrm{mL}$, Novartis Pharma, Basel, Switzerland), camptothecin (CPT; $300 \mu \mathrm{M}$ : Tocris, Bristol, UK), $0.5 \%$ TritonX 100 or plant extracts in different concentrations. After cultivation, the cells were assessed in biological tests as described.

\subsection{Cell proliferation assay: CFSE}

Effects on proliferation and viability of activated human lymphocytes were assessed in comparison to ciclosporine A (CsA) using carboxyfluorescein succinimidyl ester (CFSE), a fluorescent dye which binds to intracellular proteins. Briefly, PBMCs were re-suspended in PBS at a density of $5 \times 10^{6}$ cells/mL. CFSE ( $5 \mathrm{mM}$; Sigma, Taufkirchen, Germany) was added in $1 / 1000$ dilution, and the PBMCs were incubated for $10 \mathrm{~min}$ at $37^{\circ} \mathrm{C}$. The staining reaction was stopped by washing twice with complete medium. The cell density of the stained cells was adjusted to $2 \times 10^{6}$ cells $/ \mathrm{mL}$, following stimulation with monoclonal antibodies anti-CD3 and anti-CD28 (1:100 v/v). The cells were seeded at a density of $2 \times 10^{5}$ cells $/ \mathrm{ml}$. For the negative control, the cells remained unstimulated and untreated, and for the positive control, the cells were stimulated and left untreated. The control substance (CsA: $5 \mu \mathrm{g} / \mathrm{mL}$ ) and plant extracts (final concentrations: 100, 30, $10,3,1,0.3 \mu \mathrm{g} / \mathrm{mL}$ ) were added to cells using 96 well flat bottom plates, and were incubated for $72 \mathrm{~h}\left(37^{\circ} \mathrm{C}, 5 \% \mathrm{CO}_{2}\right)$. Afterwards, the cell proliferation was analysed using flow cytometry (FACS Calibur instrument: BD Biosciences, Becton Dickinson, Franklin Lakes, NJ).

\subsection{Cell viability assay: WST-1}

In addition, cell cytotoxicity was measured using the WST-1 assay, 
which is based on the reduction of the tetrazolium salt WST-1 to formazan by cellular dehydrogenases. Briefly, the cell density of the isolated PBMCs was adjusted to $2 \times 10^{6}$ cells $/ \mathrm{ml}$, following stimulation with monoclonal antibodies antiCD3 and antiCD28 (1:100 v/v). The cells were seeded at a density of $2 \times 10^{5}$ cells $/ \mathrm{mL}$. For the negative control, the cells remained unstimulated and untreated, and for the positive control, the cells were stimulated and left untreated. The control substances (CsA: $5 \mu \mathrm{g} / \mathrm{mL}$ and triton-X: 0.005\%) and plant extracts (final concentrations: $100,30,10,3,1,0.3 \mu \mathrm{g} / \mathrm{mL}$ ) were added to cells using 96-well flat bottom plates, and were incubated for $72 \mathrm{~h}$ $\left(37^{\circ} \mathrm{C}, 5 \% \mathrm{CO}_{2}\right)$. The cells were washed twice with PBS buffer, after which $100 \mu \mathrm{L}$ of freshly prepared WST-buffer solution was added to each well and incubated for $1 \mathrm{~h}$ at $37^{\circ} \mathrm{C}$. The viability of the cells were measured using the ELISA Reader (Tecan Reader Infinite M 200) at $450 \mathrm{~nm}$.

\subsection{Analysis of apoptosis and necrosis using annexin $V$ and propidium iodide staining}

Flow cytometry by annexin V/propidium iodide (PI) staining was performed to investigate the necrotic/apoptotic effect of the plant extracts. Briefly, activated PBMCs $\left(2 \times 10^{6}\right.$ cells $\left./ \mathrm{ml}\right)$ treated with different concentrations $(100,30,10,3,1,0.3 \mu \mathrm{g} / \mathrm{mL})$ of the plant extract for $72 \mathrm{~h}$ were washed twice and re-suspended in PBS. The cells were then incubated in the dark at ambient temperature with $50 \mu \mathrm{L}$ Annexinstaining Mastermix $(0.5 \mu \mathrm{L}$ Annexin-V stain $+50 \mu \mathrm{L}$ Annexin-Buffer dilution $(1: 9 \mathrm{v} / \mathrm{v}))$ for $15 \mathrm{~min}$. Cells were incubated for another $15 \mathrm{~min}$ in the dark after addition of $5 \mu \mathrm{L}$ PI. Unstimulated cells (NC), untreated cells (PC), treated cells with camptothecin (CPT, $300 \mu \mathrm{M})$ (control for apoptosis) and treated cells with TritonX $100(0.5 \%)$ (control for necrosis) served as controls. Thereafter, apoptosis and necrosis rates were acquired using a FACS Calibur flow cytometer.

\subsection{Analysis of CD69 and CD25 activation markers}

Freshly isolated PBMCs $\left(2 \times 10^{6}\right.$ cells $\left./ \mathrm{mL}\right)$ were stimulated (except the NC) with $100 \mu \mathrm{g} / \mathrm{mL}$ antihuman antiCD3 and antiCD28 monoclonal antibodies $(1: 100 \mathrm{v} / \mathrm{v})$. Next, the cells were seeded at a density of $2 \times 10^{5}$ cells/well and incubated together with plant extracts at concentrations $100,30,10,3,1,0.3 \mu \mathrm{g} / \mathrm{mL}$ and controls (CPT: $300 \mu \mathrm{M}$; CsA: $5 \mu \mathrm{g} / \mathrm{mL})$ for $24 \mathrm{~h}\left(37^{\circ} \mathrm{C}, 5 \% \mathrm{CO}_{2}\right)$. Incubated cells were washed twice with FACS buffer (DPBS (1x) Gibco, 10\% FCS and 5\% $\mathrm{NaN}_{3}$ ) and stained with FITC-labelled anti-human CD69, PE-labelled anti-human CD25 mAbs and APC-labelled CD4 (eBioscience, Frankfurt, Germany) for $20 \mathrm{~min}$ at $4{ }^{\circ} \mathrm{C}$. Next, the cells were washed twice with FACS buffer and resuspended. The expression of CD69 and IL-2 surface receptor achain CD25 was measured by FACS analysis using a FACSCalibur flow cytometer.

\subsection{Determination of cytokine production}

Activated cells $\left(3 \times 10^{6}\right)$ were treated for $48 \mathrm{~h}\left(37^{\circ} \mathrm{C}\right.$., $5 \%$ CO $\left.{ }^{2}\right)$ with plant extracts at concentrations $100,30,10,3,1,0.3 \mu \mathrm{g} / \mathrm{mL}$ and control (CsA: $5 \mu \mathrm{g} / \mathrm{mL}$ ); and were restimulated (except the NC) with $50 \mathrm{ng} / \mathrm{mL}$ PMA, $1 \mu \mathrm{g} / \mathrm{mL}$ Ionomycin and $1 \mu \mathrm{L} / \mathrm{mL}$ BD Golgi Plug (Sigma-Aldrich, Taufkirchen, Germany) for $4 \mathrm{~h}$ at $37^{\circ} \mathrm{C}$. Next, the cells were resuspended, washed with FACS buffer and fixed with $4 \%$ paraformaldehyde (PFA) (Sigma-Aldrich) for $10 \mathrm{~min}$ at room temperature. The cells were then permeabilised using Perm/Wash solution (Becton Dickinson, Franklin Lakes, NJ) for $15 \mathrm{~min}$ at $4{ }^{\circ} \mathrm{C}$, followed by staining with PE-conjugated anti-human IFN- $\gamma \mathrm{mAb}$ or PE-conjugated antihuman IL-2 mAb (both from eBioscience). Cytokine production was analysed with a BD FACSCalibur flow cytometer using FlowJo X Software.

\subsection{HPLC analysis}

HPLC-PDA-ELSD-ESIMS analysis was carried out on a Shimadzu HPLC system consisting of a degasser, binary high-.pressure mixing pump, autosampler, column oven and diode array detector. An Alltech E3300 ELSD detector and a Shimadzu LC-MS/MS 8030 quadrupole MS were connected via a T-splitter. Extracts were dissolved in DMSO at $10 \mathrm{mg} / \mathrm{mL}$, centrifuged for $5 \mathrm{~min}$ at $13,000 \mathrm{rpm}$ and $5 \mu \mathrm{L}$ of the supernatant were injected. HPLC-MS grade acetonitrile (Macron Fine Chemicals, solvent B) and water from a Milli-Q water purification system (Merck Millipore) were used for HPLC separation with $0.1 \%$ of formic acid (FA, Acros Organics). The gradient used for analytical HPLC on a Waters sunfire $\mathrm{C}_{18}(3.5 \mu \mathrm{m}, 3.0 \times 150 \mathrm{~mm}$ i.d., equipped with a guard column $10 \times 3.0 \mathrm{~mm}$ i.d.) was $\left[\mathrm{H}_{2} \mathrm{O}+0.1 \% \mathrm{FA}(\mathrm{A}), \mathrm{CH}_{3} \mathrm{CN}+\right.$ $0.1 \%$ FA (B); 5\% B (0-2 min), 5-100\% B (2-30 min), 100\% B (30-37 $\mathrm{min}), 100$ to $5 \% \mathrm{~B}(37-38 \mathrm{~min}), 5 \% \mathrm{~B}(38-43 \mathrm{~min})]$.

\subsection{Data analysis}

The biological assays were conducted in 3 independent experiments. The data was analysed using GraphPad Prism 8.1.0 (325). Oneway ANOVA was used to determine statistical significances, followed by Dunnett's post hoc pairwise comparisons or by paired two sample $t$ tests. For not normally distributed data, statistical significances were calculated using the Kruskal-Wallis test for independent samples. Values are presented as mean \pm SEM for the indicated number of independent experiments. The asterisks represent significant differences from controls $(* \mathrm{p}<0.05, * * \mathrm{p}<0.01, * * * \mathrm{p}<0.001)$.

\section{Results}

\subsection{Effects of Namibian plant extracts on proliferation of T-lymphocytes}

In order to analyse the immunomodulatory activity of selected Namibian plant extracts, the effects on cell growth was evaluated at varying concentrations $(0.3-30 \mu \mathrm{g} / \mathrm{mL})$. CFSE-labelled cells were used to determine the impact of Namibian plant extracts on cell division of PBMCs (Fig. 2). In the presence of ciclosporine A (CsA), the activated cells did not proliferate $(2.63 \% \pm 1.18)$ compared to the stimulated cells alone (positive control: PC), which showed a $100 \%$ proliferation. Similarly, the extracts showed a reduction in proliferated cells in a concentration dependent manner. At concentrations as low as $3 \mu \mathrm{g} / \mathrm{mL}$ (A.n.e: $0.4 \% \pm 0.1$, C.d.m.: $0.6 \% \pm 0.1$ and G.f.m.: $7 \% \pm 0.8$ ), proliferation of $<10 \%$ was observed, with the exception of A.n.e. (64 $\% \pm 3.0)$ and C.d.e $(39 \% \pm 3.8)$ extracts. EtOAc extract of $G$. fruticosus (G.f.e.) were the most potent $(0.3 \mu \mathrm{g} / \mathrm{mL}: 0.6 \% \pm 0.2 ; 1 \mu \mathrm{g} / \mathrm{mL}$ : $0.8 \% \pm 0.2 ; 3 \mu \mathrm{g} / \mathrm{mL}: 0.4 \% \pm 0.1 ; 10 \mu \mathrm{g} / \mathrm{mL}: 0.2 \% \pm 0.04 ; 30 \mu \mathrm{g} /$ $\mathrm{mL}: 11 \% \pm 2.4 \mu \mathrm{g} / \mathrm{mL}$ in inhibiting proliferation.

The plant extracts were further analysed to determine their impact on the viability of PBMCs using the WST-1 assay (Fig. 3). The results demonstrate a decreased viability of human immunocompentent cells compared to stimulated cells alone $(100 \%)$. The inhibitory effects on viability of the PBMCs were mostly seen in the EtOAc extract of G. fruticosus (G.f.e.) $(0.3 \mu \mathrm{g} / \mathrm{mL}: 10 \% \pm 1.6 ; 1 \mu \mathrm{g} / \mathrm{mL}: 9 \% \pm 1.0$; $3 \mu \mathrm{g} / \mathrm{mL}: 10 \% \pm 1.4 ; 10 \mu \mathrm{g} / \mathrm{mL}: 15 \% \pm 1.8 ; 30 \mu \mathrm{g} / \mathrm{mL}: 40 \% \pm 5.2$ ).

\subsection{Effects of Namibian plant extracts on lymphocyte apoptosis and necrosis}

To disregard possible cytotoxic effects as cause of the observed reduced cell proliferation, the apoptotic and necrotic effects of the extracts were evaluated (Fig. 4). Staining PBMCs with annexin-PI enables the discrimination between viable, apoptotic and necrotic cells. The data shows that the EtOAc extracts of $G$. fruticosus (G.f.e.), induced apoptosis, mostly at increased concentrations (Fig. 4a). At concentrations of 10 and $30 \mu \mathrm{g} / \mathrm{mL}$ extracts (G.f.e: $253 \% \pm 5.7$ and 


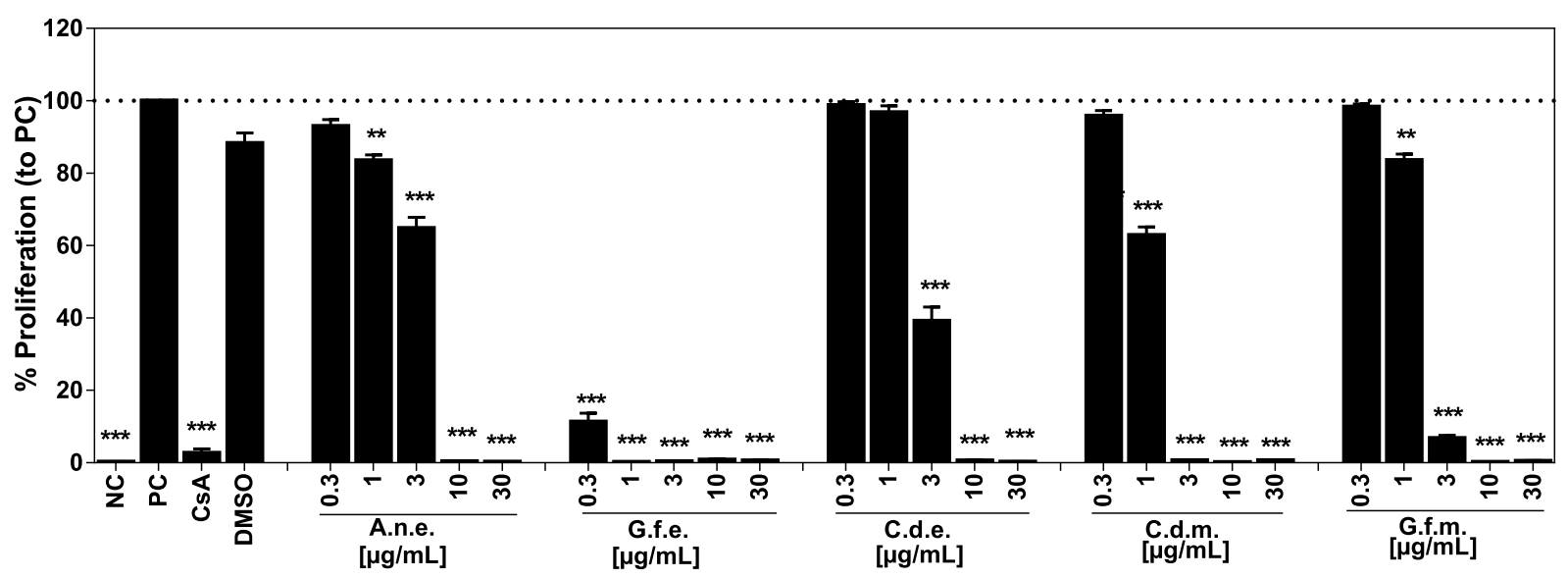

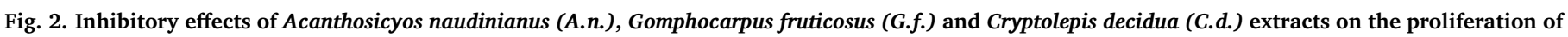

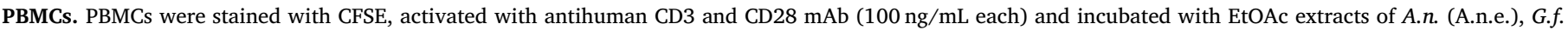

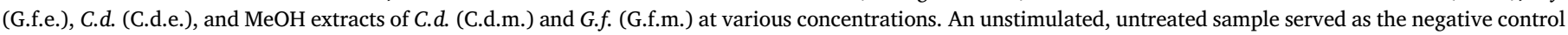

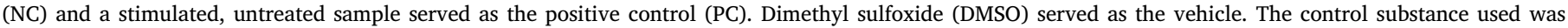
ciclosporin A (CsA $5 \mu \mathrm{g} / \mathrm{mL})$. Data from 3 independent tests are presented as means \pm SEM in relation to PC. $* \mathrm{p}<0.05, * * \mathrm{p}<0.01, * * * \mathrm{p}<0.001$.

$295 \% \pm 6.7$, respectively) were comparable $(\mathrm{p}>0.5)$ to the control $\mathrm{CPT}(279 \% \pm 6.3)$. Furthermore, the extracts under investigation showed no significant necrotic effects (Fig. 4b). The control TX $(2691 \% \pm 544)$ significantly increased necrosis, compared to extracts and the positive control ( $\mathrm{PC}=100 \%$ ). These data indicate that the inhibitory effects of low extract concentrations on PBMCs proliferation is not mediated by cytotoxic effects.

\subsection{Effects of Namibian plant extracts on activation of T-lymphocytes}

The non-cytotoxic effects of the selected plant extracts warranted for investigation into the regulatory mechanism. Activation markers such as CD25 and CD69 are normally expressed when T-lymphocytes are stimulated by antigen binding of T-cell receptors. Post activation, the percentage of CD25 (Fig. 5a) and CD69 (Fig. 5b) was strongly induced in stimulated lymphocytes (PC) compared to unstimulated cells (NC) (Fig. 5). The data also indicate that the expression of both markers was significantly reduced for the treated cells compared to untreated cells (positive control, $\mathrm{PC}=100 \%$ ) in a concentration-dependent manner. EtOAc extracts of A. naudinianus (A.n.e) and G. fruticosus (G.f.e), showed a reduction in expression in CD25 starting in concentrations of only $3 \mu \mathrm{g} / \mathrm{mL}$ and $1 \mu \mathrm{g} / \mathrm{mL}$, respectively. These two extracts also had significant reduction of CD69 expression starting at concentrations of $10 \mu \mathrm{g} / \mathrm{mL}$.

\subsection{Effects of Namibian plant extracts on cytokine secretion of T- lymphocytes}

Further analysis on the influence of plant extracts on the effector functions of T-lymphocytes was performed. Stimulation of T-lymphocytes leads to the activation and expression of the cytokines interleukin 2 (IL-2) and interferon $\gamma$ (IFN- $\gamma$ ), thereby initiating T-cell proliferation. Consequently, the effects on IL-2 and IFN- $\gamma$ secretion of the extracts under investigation were analysed (Fig. 6). The results demonstrate that the secretion of both IL-2 $(33 \% \pm 15)$ and IFN- $\gamma(2 \% \pm 0.5)$ was diminished by ciclosporine A (CsA) compared to positive control ( $\mathrm{PC}=100 \%$ ), and also in the presence of extracts. A dose-dependent reduction of IL-2 for EtOAc extracts of A. naudinianus (A.n.e), G. fruticosus (G.f.e.), and C. decidua (C.d.e.); and $\mathrm{MeOH}$ extracts of $C$. decidua (C.d.m.) and G. fruticosus (G.f.m.) were observed. (Fig. 6a). For G. fruticosus (G.f.e.) and C. decidua (C.d.m.) this reduction in IL-2 was observed in already very low concentrations (starting from $0.3 \mu \mathrm{g} / \mathrm{mL}$ ).

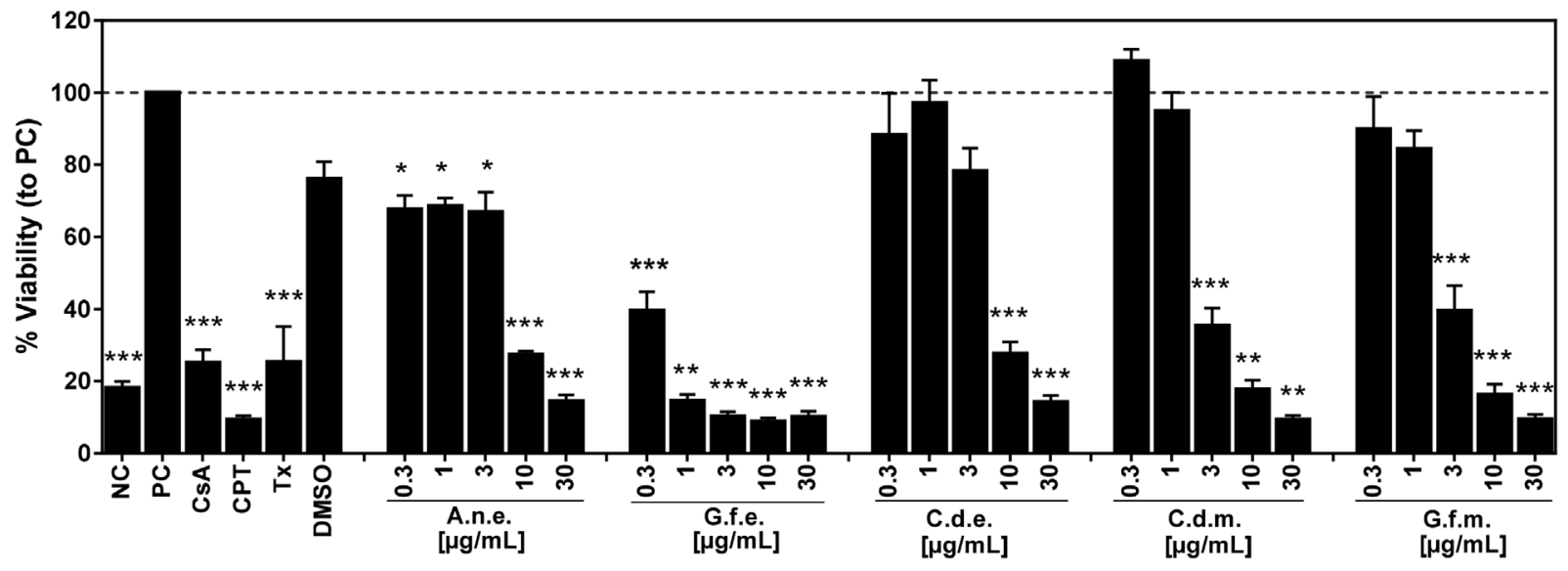

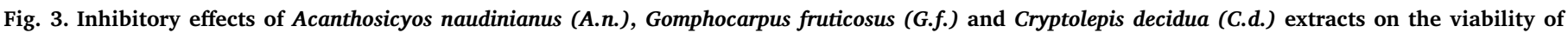

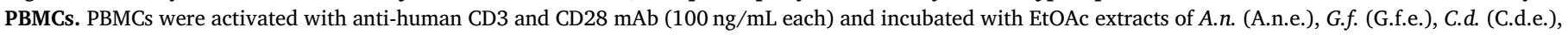

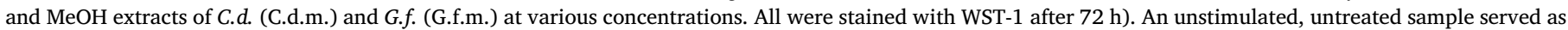

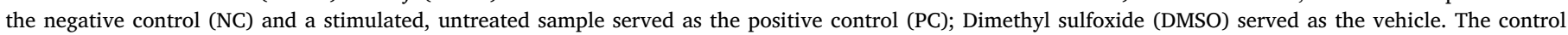

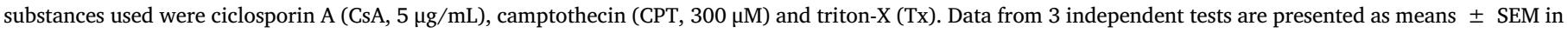
relation to $\mathrm{PC}$. $* \mathrm{p}<0.05, * * \mathrm{p}<0.01, * * * \mathrm{p}<0.001$. 
A

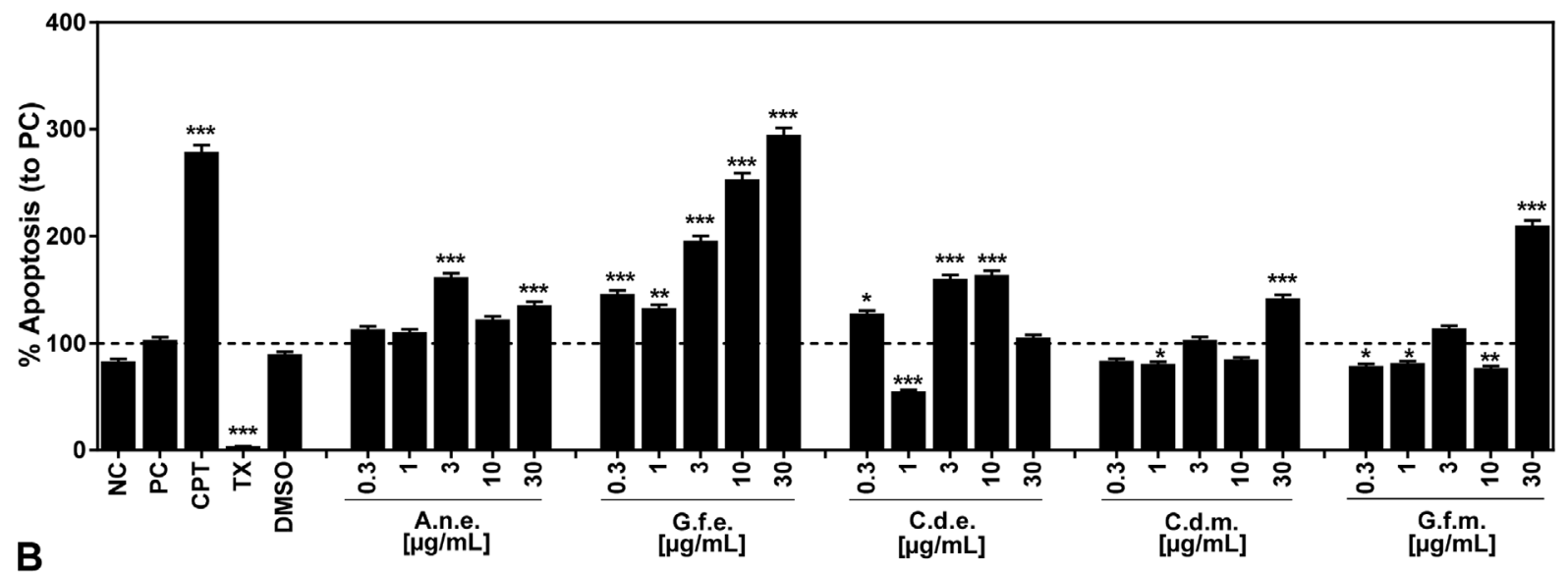

B

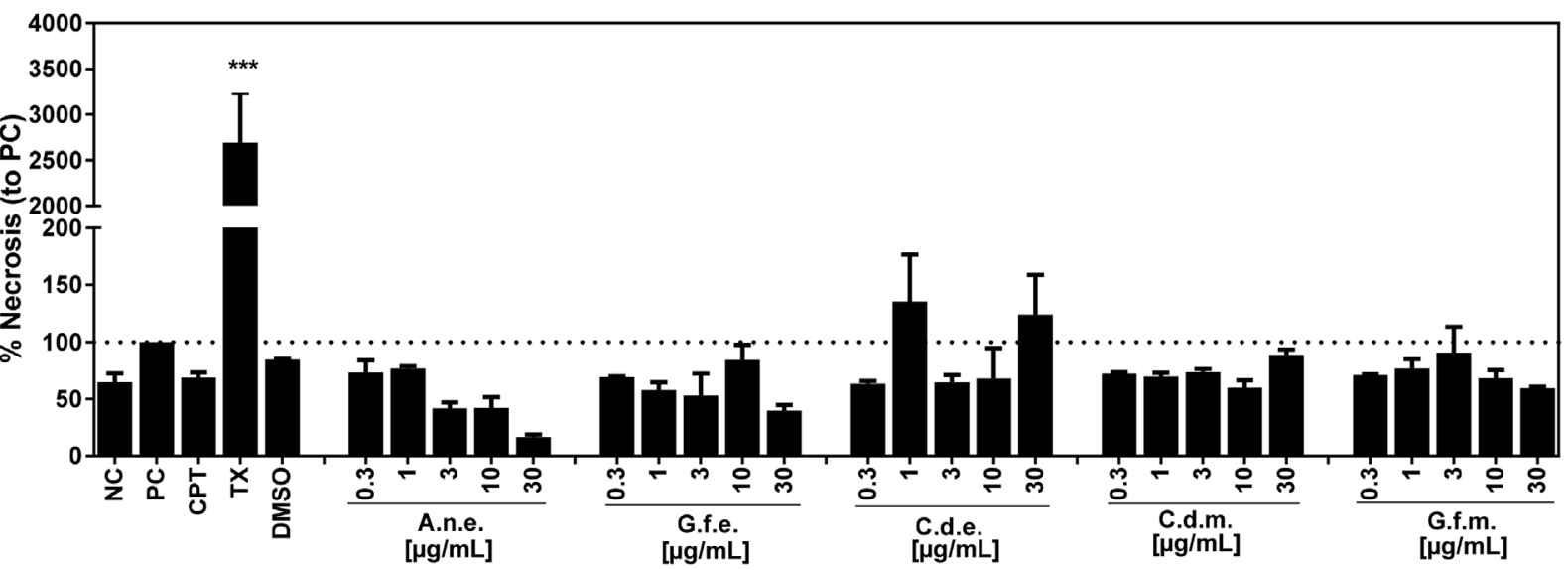

Fig. 4. Apoptotic (A) and necrotic (B) effects of Acanthosicyos naudinianus (A.n.), Gomphocarpus fruticosus (G.f.), and Cryptolepis decidua (C.d.) extracts on PBMCs. PBMCs were activated with anti-human CD3 and CD28 mAb (100 ng/mL each) and incubated with and EtOAc extracts of A.n. (A.n.e.), G.f. (G.f.e.), C.d. (C.d.e.), and $\mathrm{MeOH}$ extracts of C.d. (C.d.m.) and G.f. (G.f.m.) at various concentrations; and stained with annexin-PI. An unstimulated, untreated sample served as the negative control: NC and a stimulated, untreated sample served as the positive control (PC). Dimethyl sulfoxide (DMSO) served as the vehicle. The control substance used was camptothecin (CPT, $300 \mu \mathrm{M})$ and triton-X (Tx). Data from 3 independent tests are presented as means \pm SEM in relation to PC. $* \mathrm{p}<0.05, * * \mathrm{p}<0.01$, $* * * \mathrm{p}<0.001$.

IFN- $\gamma$ levels were, at low concentrations $(3 \mu \mathrm{g} / \mathrm{mL})$ only reduced by G. fruticosus (G.f.e.) (Fig. 6b).

\subsection{HPLC analysis}

The phytochemical profiles of the plant extracts were recorded via HPLC using an electron light scattering detector (ELSD), a photo diode array detector (PDA) and a quadrupol MS detector. The chromatograms can be found in the supporting information (Figs. S1-S3). From ELSD, the peak at 13.3 min was most abundant in the EtOAc extract of Acanthosicyos naudinianus (Fig. S1, see Supplementary Information). It showed a mass of $m / z 487$ in positive mode and only very little UV absorption above $220 \mathrm{~nm}$. Other significant peaks showed masses at $\mathrm{m} /$ z 497, 501 and 499 in positive mode.

In the EtOAc extract of Gomphocarpus fruticosus (Fig. S2, see Supplementary Information), ELSD showed larger peaks only after $30 \mathrm{~min}$ with no corresponding signals in MS or PDA. One other small ELSD peak is visible at $18.7 \mathrm{~min}$, corresponding to a mass in MS at $\mathrm{m} / z 570$ in positive mode and an UV Maximum at $219 \mathrm{~nm}$. Other representative masses found were $m / z 556$, and 519 in positive mode. The MeOH extract showed one ELSD peak at $10.8 \mathrm{~min}$, corresponding to UV maxima at 255 and $350 \mathrm{~nm}$ and a mass of $\mathrm{m} / z 611$ in positive mode.

In the EtOAc extract of Cryptolepis decidua (Fig. S3, see Supplementary Information), the ELSD trace shows only one peak without corresponding MS or PDA signal. Other notable peaks were found between 24 and 27 min showing MS signals in positive mode with corresponding UV maxima at $\mathrm{m} / z 279$ (UV $227 \mathrm{~nm}$ ), 295 (224 and $278 \mathrm{~nm})$ and $297(224 \mathrm{~nm})$ and $m / z 391(206,228$ and $325 \mathrm{~nm}) . M / z$ 391 was also found at 11.6 and 13.1 min with similar UV maxima. Also, the $\mathrm{MeOH}$ extract showed the same peaks containing $m / z 391$ along with a major peak at $10.0 \mathrm{~min}$ with $\mathrm{m} / \mathrm{z} 229$ in positive mode with a corresponding UV maximum at $271 \mathrm{~nm}$.

\section{Discussion}

Traditional herbal medicine is used by many developing countries to address their primary health care needs (Abdullahi, 2011). Medicinal plants as alternative or complementary medicine, have become increasingly important throughout the world, due to them being accessible, cost-effective and having less side effects (Del Prete et al., 2012). By the same token, people are becoming more health conscious and opt for herbal treatments instead of conventional medicine. In Namibia traditional herbal medicine has up to now not been integrated into mainstream medicine even though in some communities, especially in economically poor areas, herbal concoctions are the only option in view of limited access to healthcare facilities. However, medicinal plants are used anecdotally and based on past experiences, hence they lack scientific validation (Ozioma and Chinwe, 2019). This validation of the traditional herbal treatments will allow their safe, cheap and effective use and provide a basis for their integration into mainstream healthcare 
A
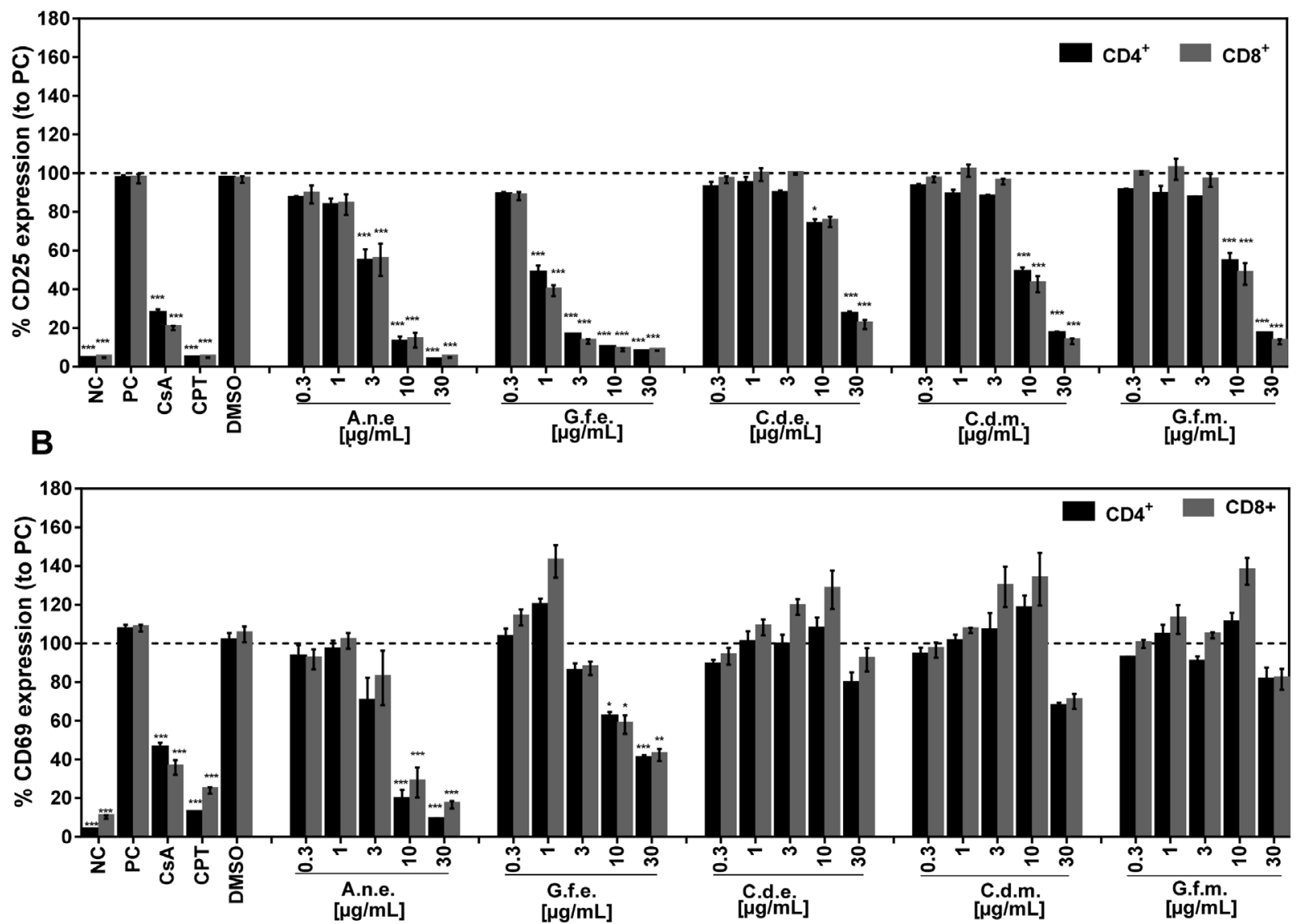

Fig. 5. Effects of Acanthosicyos naudinianus (A.n.), Gomphorcapus fruticosus (G.f.) and Cryptolepis decidua (C.d.) extracts on the activation of CD4 ${ }^{+}$and CD8 $^{+}$T-lymphocytes. Lymphocytes were activated with antihuman CD3 and CD28 mAb (100 ng/mL each) and incubated with and EtOAc extracts of A.n. (A.n.e.), G.f. (G.f.e.), C.d. (C.d.e.), and $\mathrm{MeOH}$ extracts of C.d. (C.d.m.) and G.f. (G.f.m.) at various concentrations for $72 \mathrm{~h}$; and stained with FITC-labelled antihuman CD69, PElabelled anti human CD25 mAbs and APC-labelled CD4. The expression of markers CD25 and CD69 was analysed using flow cytometry. An unstimulated, untreated sample served as the negative control: NC and a stimulated, untreated sample served as the positive control (PC). Dimethyl sulfoxide (DMSO) served as the vehicle. The control substances used were ciclosporin A (CsA, $5 \mu \mathrm{g} / \mathrm{mL})$, and camptothecin $(\mathrm{CPT}, 300 \mu \mathrm{M})$. Data from 3 independent tests are presented as means \pm SEM in relation to PC. $* \mathrm{p}<0.05, * * \mathrm{p}<0.01, * * * \mathrm{p}<0.001$.

in Namibia.

Traditionally, Acanthosicyos naudinianus, Gomphocarpus fruticosus and Cryptolepis decidua are used to treat conditions such as pain, fever and skin rashes, which are symptoms of inflammatory responses (Gratton and Imboden, 2010; Sonoda et al., 2017), a criteria for selecting the plants under investigation. A few studies relating to the biological activities have been done, including anticancer: A. naudinianus, antibacterial (Saidu et al., 2014), anti-inflammatory, antioxidant, anticancer and anti-viral (HPV-1) (Twilley et al., 2017): G. fruticosus. None of the herbs, however, have been investigated for immunomodulating properties using PBMCs. A preliminary screening was conducted to select extracts with anti-inflammatory activity for further testing in this study, this excluded the $\mathrm{MeOH}$ extract of $A$. naudinianus (A.n.m.). All three plants significantly and dose dependently supressed PBMC proliferation with two complementary methods, namely the CFSE and the WST-1 assay (Figs. 2 and 3), of which $G$. fruticosus exhibited the highest activity. It is noteworthy, that the inhibition of proliferation by the EtOAc extract of $G$. fruticosus was observed at low concentrations $(0.3 \mu \mathrm{g} / \mathrm{mL})$. The reduction in proliferation of PBMCs at this low concentration range was not of a cytotoxic nature as no significant dose related necrotic effects were observed (Fig. 4). As for the $\mathrm{MeOH}$ extract of $G$. fruticosus a significant reduction in PBMCs was observed at concentrations $1 \mu \mathrm{g} / \mathrm{mL}$ (CFSE) and $3 \mu \mathrm{g} / \mathrm{mL}$ (WST-1). The same can be said for the extracts being of a nontoxic nature - no significant effects of necrosis was observed. This is in correlation with a study by Twilley et al. (2017) who reported nontoxic effects against the human embryonic kidney 293 (HEK-293) cells and anti-inflammatory activity demonstrated by a $41.32 \%$ COX-2 inhibition at $10 \mu \mathrm{g} / \mathrm{mL}$ following treatment of with an ethanolic leaf extract of G. fruticosus. MeOH extracts of C. decidua (C.d.m.) and EtOAc extracts $C$. decidua (C.d.e.) and A. naudinianus (A.n.e.) also suppressed proliferation of PBMCs and also showed nontoxic activities. These activities correlate with reduced effects of activation marker and cytokine production.

The cytokine production and expression of activation markers appear to be the potential upstream mediators of the reduced T-cell proliferation observed in the current study. All the extracts under investigation reduced the expression of CD25 and CD69 surface activation markers (Fig. 5), and IL-2 and IFN- $\gamma$ secretion (Fig. 6). Upon activation of T-lymphocytes during an immune response, production of various cytokines including IL-2, IFN- $\gamma$, and IL-4 is initiated and in turn expands T-cells, whereas other cytokines influence differentiation of naive $\mathrm{CD}^{+}{ }^{+}$T-cells into either Th1 (IFN- $\gamma$ ) or Th2 (IL-4) subsets (Henderson et al., 2012). T-lymphocyte proliferation can also be induced by the expression or upregulation of surface markers CD69 (early activation marker) and CD25 (late activation marker) (Bajnok et al., 2017). Even though T-cells are responsible for clearance of pathogens, they are also responsible for pathology, hyper-inflammation and tissue 
A
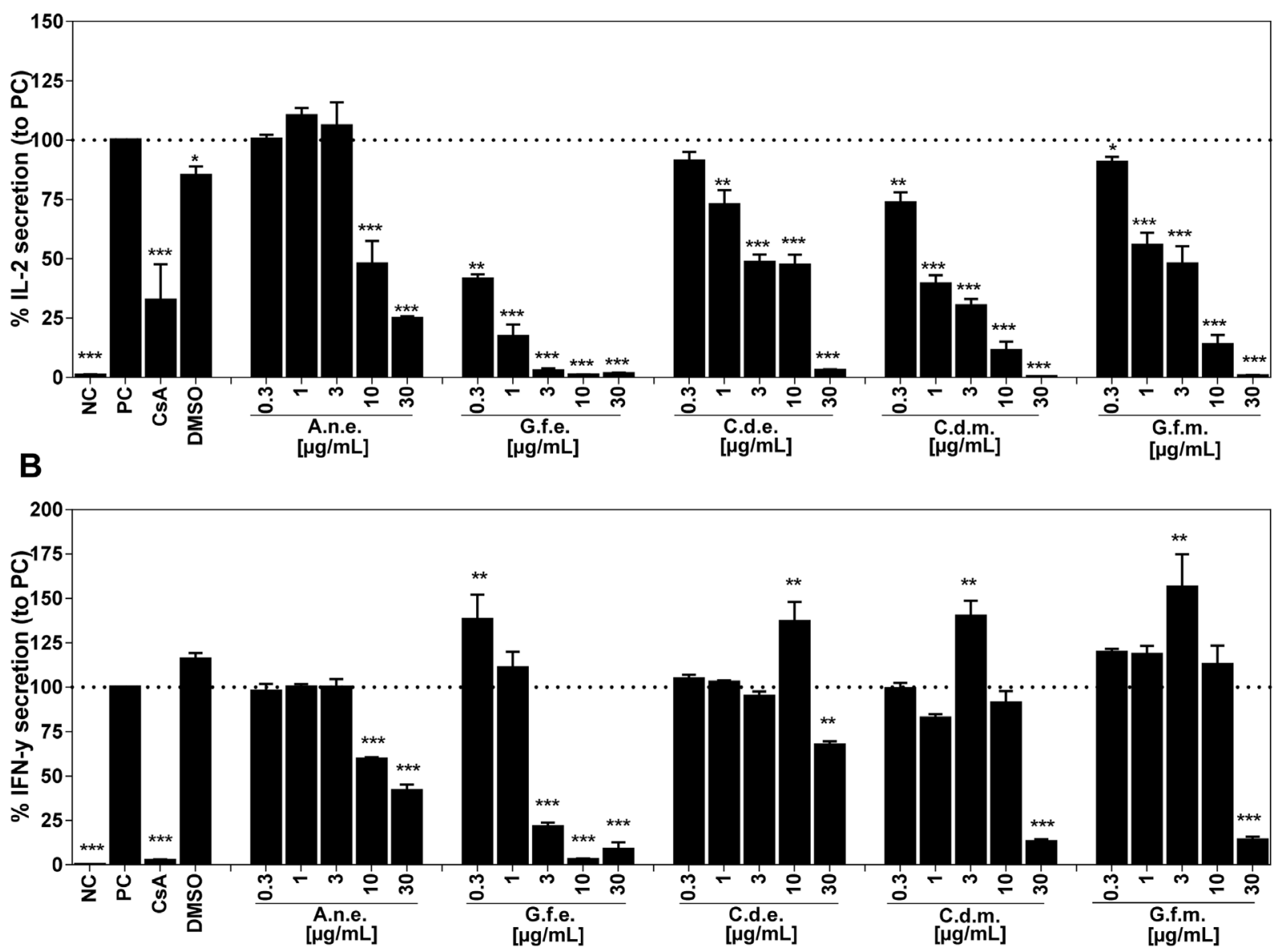

Fig. 6. Effects of Acanthosicyos naudinianus (A.n.), Gomphocarpus fruticosus (G.f.) and Cryptolepis decidua (C.d.) extracts on secretion of IL-2 and IFN- $\gamma$ by Tlymphocytes. Lymphocytes were activated with anti-human CD3 and CD28 mAb (100 ng/mL each) and incubated with and EtOAc extracts of A.n. (A.n.e.), G.f. (G.f.e.), C.d. (C.d.e.), and $\mathrm{MeOH}$ extracts of C.d. (C.d.m.) and G.f. (G.f.m.) at various concentrations for $72 \mathrm{~h}$; and stained with PE-conjugated anti-human IFN- $\gamma \mathrm{mAb}$ and PE-conjugated anti human IL-2 mAb. Cytokine production was analysed using flow cytometry. An unstimulated, untreated sample served as the negative control (NC) and a stimulated, untreated sample served as the positive control (PC). Dimethyl sulfoxide (DMSO) served as the vehicle. The control substance used was ciclosporin A (CsA, $5 \mu \mathrm{g} / \mathrm{mL}$ ). Data from 3 independent tests are presented as means \pm SEM in relation to PC. $* \mathrm{p}<0.05, * * \mathrm{p}<0.01, * * * \mathrm{p}<0.001$.

damage. The suppression of the T-lymphocyte related immune response is essential in cases where the adaptive immune system is overactive or unstable, as it is in autoimmune diseases or hyper-inflammatory infectious diseases which can present with prolonged fever, pain or skin rashes.

In the present experiments, a substantial decrease in cytokine formation were observed as a result of exposure of PBMCs to plant extracts. Cytokines are important in inflammatory responses (Mazzone et al., 2001; Zhang and An, 2007) including IL-2 (Hoyer et al., 2008) and IFN- $\gamma$ (Zhang and An, 2007). The extracts had the capacity to reduce cytokine production by reducing the expression of IL- 2 and IFN- $\gamma$ (Fig. 6). This, in turn, indicates that the plant extracts have anti-inflammatory effects. Hence, the plants can be encouraged to be used for the treatment of inflammatory related illnesses, however further experiments have to be done to ascertain these effects. On a different note, according to Che et al. (2013) polyherbal remedies or use of combination treatment regimen have attributed to additive or synergistic therapeutic effects compared to when used alone. Studies have also shown that conventional drugs are combined with additional herbal substances to increase the effects of treatment regimens, and because it is cost effective (Ameade et al., 2018). Therefore, the plants investigated in this study could be used in combination therapies with each other or with conventional medicines to enhance the observed effects. The use of medicinal plants in combination with anti- inflammatory drugs such as Tramacet (tramadol-acetaminophen) can help lower the dose of the drug resulting in less adverse side-effects. This should be taken into advisement, particularly from health care professionals, as the concurrent use of herbal medicine and orthodox medicine may have undesirable pharmacokinetic and pharmacodynamic effects (Rivera et al., 2013).

The extraction of compounds is of utmost importance, as this influences the biological activity of extracts (Liu, 2008). Knowledge of the phytochemicals of interest and their abundance is useful in selecting a method of extraction (Pandey and Tripathi, 2014). There are several approaches with tremendous advantages such as pre-soaking, liquid ammonia pretreatment, and co-digestion. All of the above processes can change plant cells either morphologically or breaking down inter-lignin bonds (Hassan et al., 2017), allowing compounds to be released thereby increasing the number of compounds extracted. For instance, the size of plant particulate matter has a great effect on the yield; and using enzymes for cell wall degradation in sample preparation has a major impact on particle size (Azwanida, 2015). For this study, sequential extraction was done using maceration methods. The latter is involved in the breaking of the cell wall of plant cells to release compounds (Azwanida, 2015). Sasidharan et al. (2010) recommend that methods of extract preparation should be based on those used in ethnomedicinal settings, which was water for the plants used in this study, however, EtOAc and $\mathrm{MeOH}$ were used as solvents because organic solvents are 
more effective in isolation of compounds (Hassan et al., 2017).

A primary phytochemical analysis on the basis of HPLC-PDA-ELSDESI-MS data was conducted to tentatively identify predominant compound classes in the respective extracts. In the EtOAc extract of Acanthosicyos naudinianus (Fig. S3, see Supplementary Information), the mass ( $\mathrm{m} / \mathrm{z} 487$ in positive mode) of the main peak could be explained by a range of cucurbitane type triterpenes isolated from Momordica charantia (Jiang et al., 2016), some of which were described with cancer preventive properties (Zhang et al., 2012). The other masses found might be related to cucurbitacins isolated from the related species Acanthosicyos horridus (Hylands and Magd, 1986). Some cucurbitacins have been described as anti-inflammatory (Komissarenko et al., 1995; Kaushik et al., 2015) and might contribute to the activity of the extract.

In the EtOAc extract of Gomphocarpus fruticosus (Fig. S2, see Supplementary Information), MS ( $\mathrm{m} / \mathrm{z} 518$ in positive mode) together with a UV maximum at $219 \mathrm{~nm}$ from the butenolide lactone ring indicates the presence of glycosylated cardenolides similar to gomphoside or gomphotin, compounds which have been isolated from the leaves of G. fruticosus (Komissarenko et al., 1995). The even masses 570 and $556 \mathrm{~m} / \mathrm{z}$ in positive mode suggested nitrogen containing compounds, possibly related to uscharin, a cytotoxic nitrogen and sulphur containing cardenolide (Roy et al., 2005) found in other Asclepiadaceae. The main component $(611 \mathrm{~m} / \mathrm{z}$ in positive mode) in the $\mathrm{MeOH}$ extract was most likely a flavon-on diglycoside similar to hesperidin.

To our knowledge, no compounds have been isolated from Cryptolepis decidua so far. For the masses $m / z$ 279, 295 and 297 found in the EtOAc extract from Cryptolepis decidua (Fig. S3, see Supplementary Information), a series of indole alkaloids similar to vincamenine (isolated from Melodinus khasianus, Apocynaceae) (Cheng et al., 2016), vinburnine and eburnamine (isolated from Kopsia jasminifolia, Apocynacae) (Kitajima et al., 2014) might be responsible for the activity observed in this study. Vinburnine is mentioned in a patent as a possible agent in combination therapy against $\mathrm{NF \kappa B}$ mediated diseases (Steiger et al., 2011). For $m / z 391$ in positive mode found in both, the $\mathrm{MeOH}$ and the EtOAc extract, three possible compounds, isolated from different Apocynaceae (Cheng et al., 2016), were found. All three, the irioid loganin from Alstonia scholaris (Feng et al., 2008), the steroidal alkaloid holadysenterine from Holoarrhena antidysenterica (Kumar et al., 2007) and the indole alkaloid rauvoloid D from Rauwolfia yunnanensis (Geng and Liu, 2013) were possible matches and had no reported immunomodulatory or anti-inflammatory activity. No information is available on the major ELSD peaks found in the extracts of Gomphocarpus fruticosus and Cryptolepis decidua other than their lipophilicity and lack of UV absorbance.

\section{Conclusion}

The extracts of the plants in this study inhibited PBMC proliferation. This activity can be related to the observed reduction in the expression of CD25 and CD69 markers, and cytokine (i.e. IL-2 and IFN- $\gamma$ ) production. Furthermore, the data demonstrate that the extracts of A. naudinianus, $G$. fruticosus, and $C$. decidua interfere with the function of immunocompetent cells in vitro, suggesting an anti-inflammatory mode-of-action. While cucurbitacins are likely the active constituents in the extract of $A$. naudinianus and indole alkaloids for the extracts of $\mathrm{C}$. decidua, all extracts should be subjected to activity guided fractionations to identify the specific compounds responsible. The results of the study also provide a rational basis for the traditional use of the plants, however, further studies are required to corroborate these effects. These include in vivo studies to investigate the therapeutic potential of the plants in inflammatory disorders; specific signal pathway assays such as the effect of plant extracts on transcription factors (i.e. activator protein 1 (AP-1), nuclear factor of activated T-cells (NFAT) and nuclear factor kappa-light-chain-enhancer of activated B-cells (NF-кB)); and finally the investigation of the resorption properties of the plant compounds using the Caco-2 permeability assay to determine absorption of relevant compounds in the extracts intestinally.

\section{Funding}

This work was funded by the German Research Foundation (DFG) (HU2687/1-1). Part of this work was conducted in the Biomedical Research Laboratory, Multidisciplinary Research Centre, University of Namibia, supported by local funding.

\section{Authors' contributions}

R.H. and C.G. conceived, organized and supervised the project. C.I.D. and D.R.M applied for the research/collection permits, collected and processed all plant materials, C.I.D conducted all experiments. C.G. and C.I.D. analysed flow cytometry data. C.I.D. wrote the draft article. J.R. conducted the HPLC analysis and wrote the sections on the HPLC. All authors read and approved the final manuscript.

\section{Consent for publication}

Not applicable.

\section{Ethics statement}

A research collection permit (authorization no. 2017070703) was granted by the Ministry of Environment and Tourism (MET) of Namibia through the National Commission on Research Science and Technology (NCRST) to authorise collection of plant material and its transportation to Germany, Freiburg where most of the experimental research was conducted. The protocols for all experiments conducted on human material were approved by the Ethics committee of the University of Freiburg $(235 / 11 ; 22.06 .11)$.

\section{Declaration of competing interest}

The authors declare that they have no competing interests.

\section{Acknowledgement}

Authors wish to thank Seema Devi, Chiara Falanga, Moritz Winker and Ami Zimmermann-Klemd for their technical support and valuable contributions to this project.

\section{Abbreviations}

A.n.e. Acanthosicyos naudinianus ethyl acetate extract

AID Autoimmune disorders

$\mathrm{CaCl}$ Calcium chloride

CD Cluster of differentiation

C.d.e. Cryptolepis decidua ethyl acetate extract

CFSE Carboxyfluorescein succinimidyl ester

C.d.m. Cryptolepis decidua methanol extract

$\mathrm{CO}_{2} \quad$ Carbon dioxide

CPT camptothecin

CsA Ciclosporine A

DMSO dimethyl sulfoxide

ELISA enzyme-linked immunosorbent assay

EtOAc ethyl acetate

FACS Fluorescence-activated cell sorting

FCS Fetal calf serum

FITC Fluorescein isothiocyanate

G.f.e. Gomphocarpus fruticosus ethyl acetate extract

G.f.m. Gomphocarpus fruticosus methanol extract

h Hour

HIV Human immunodeficiency virus 


$\begin{array}{ll}\text { IFN } & \text { Interferon } \\ \text { IL- } & \text { Interleukin } \\ \text { mAb } & \text { Monoclonal antibody } \\ \text { MCF-7 } & \text { Michigan Cancer Foundation-7 } \\ \text { MeOH } & \text { methanol } \\ \text { MET } & \text { Ministry of Environment and Tourism } \\ \text { mg } & \text { Milligram } \\ \text { mL } & \text { Millilitre } \\ \text { NC } & \text { Negative control } \\ \text { NCRST } & \text { National Commission on Research, Science and Technology } \\ \text { ng } & \text { Nanogram } \\ \text { p } & \text { P-value } \\ \text { PBMCs } & \text { Peripheral blood mononuclear cells } \\ \text { PBS } & \text { Phosphate buffer saline } \\ \text { PC } & \text { Positive control } \\ \text { PFA } & \text { Paraformaldehyde } \\ \text { PI } & \text { Propidium iodide } \\ \text { RPMI } & \text { Roswell Park Memorial Institute medium } \\ \text { SEM } & \text { Standard error of means } \\ \text { SLE } & \text { Systemic lupus erythematosus } \\ \text { TB } & \text { Tuberculosis } \\ \text { UACC62 } & \text { University of Arizona Cell Culture-62 }\end{array}$

WST-1 water-soluble tetrazolium or 2-(4-iodophenyl)-3-(4-nitrophenyl)-5-(2,4-disulfophenyl)-2H-tetrazolium, monosodium salt

ug microgram

\section{Appendix A. Supplementary data}

Supplementary data to this article can be found online at https:// doi.org/10.1016/j.jep.2020.112683.

\section{References}

Abdullahi, A.A., 2011. Trends and challenges of traditional medicine in Africa. Afr. J. Tradit., Complementary Altern. Med. 8, 115-123. https://doi.org/10.4314/ajtcam. v8i5S.5.

Abe, F., Mori, Y., Okabe, H., Yamauchi, T., 1994. Steroidal constituents from the roots and stems of Aclepias fruticosa. Chem. Pharmaceut. Bull. 42, 1777-1783. https://doi.org/ 10.1248/cpb.42.1777.

Ameade, E.P.K., Ibrahim, M., Ibrahim, H.-S., Habib, R.H., Gbedema, S.Y., 2018. Concurrent use of herbal and orthodox medicines among residents of Tamale, northern Ghana, who patronize hospitals and herbal clinics. Evid. base Compl. Alternative Med. 2018, 1-8. https://doi.org/10.1155/2018/1289125.

Arendt, E.K., Zannini, E., 2013. Barley. In: Arendt, E.K., Zannini, E. (Eds.), Cereal Grains for the Food and Beverage Industries, Woodhead Publishing Series in Food Science, Technology and Nutrition. Woodhead Publishing, pp. 155-201e. https://doi.org/10. 1533/9780857098924.155.

Azwanida, N.N., 2015. A review on the extraction methods use in medicinal plants, principle, strength and limitation. Med. Aromatic Plants 4, 1-6. https://doi.org/10. 4172/2167-0412.1000196.

Bajnok, A., Ivanova, M., Rigó Jr., J., Toldi, G., 2017. The distribution of activation markers and selectins on peripheral T lymphocytes in preeclampsia. Mediat. Inflamm. 2017, 1-7. https://doi.org/10.1155/2017/8045161.

Bansal, A., Chhabra, V., Rawal, R.K., Sharma, S., 2014. Chemometrics: a new scenario in herbal drug standardization. Journal of Pharmaceutical Analysis 4, 223-233. https:// doi.org/10.1016/j.jpha.2013.12.001.

Belščak-Cvitanović, A., Valinger, D., Benković, M., Tušek, A.J., Jurina, T., Komes, D., Kljusurić, J.G., 2017. Integrated approach for bioactive quality evaluation of medicinal plant extracts using HPLC-DAD, spectrophotometric, near infrared spectroscopy and chemometric techniques. Int. J. Food Prop. 20, S2463-S2480. https://doi. org/10.1080/10942912.2017.1373122.

Bosma-den Boer, M.M., van Wetten, M.-L., Pruimboom, L., 2012. Chronic inflammatory diseases are stimulated by current lifestyle: how diet, stress levels and medication prevent our body from recovering. Nutr. Metabol. 9, 32. https://doi.org/10.1186/ 1743-7075-9-32.

Brumbaugh, M.A., 2015. Medicinal Plants of Namibia (Thesis). The University of Arizona, Tucson, Arizona.

Camara, N.O.S., Lepique, A.P., Basso, A.S., 2012. Lymphocyte differentiation and effector functions. J. Immunol. Res. 2012, 1-3. https://doi.org/10.1155/2012/510603.

Che, C.T., Wang, Z.J., Chow, M.S., Lam, C.W., 2013. Herb-herb combination for therapeutic enhancement and advancement: theory, practice and future perspectives. Molecules 18, 5125-5141. https://doi.org/10.3390/molecules18055125.

Cheikhyoussef, A., Shapi, M., Matengu, K., Mu Ashekele, H., 2011. Ethnobotanical study of indigenous knowledge on medicinal plant use by traditional healers in Oshikoto region, Namibia. J. Ethnobiol. Ethnomed. 7 (10). https://doi.org/10.1186/17464269-7-10.

Chen, L., Deng, H., Cui, H., Fang, J., Zuo, Z., Deng, J., Li, Y., Wang, X., Zhao, L., 2017. Inflammatory responses and inflammation-associated diseases in organs. Oncotarget 9, 7204-7218. https://doi.org/10.18632/oncotarget.23208.

Cheng, G.-G., Li, D., Hou, B., Li, X.-N., Liu, L., Chen, Y.-Y., Lunga, P.-K., Khan, A., Liu, Y.P., Zuo, Z.-L., Luo, X.-D., 2016. Melokhanines A-J, bioactive monoterpenoid indole alkaloids with diverse skeletons from Melodinus khasianus. J. Nat. Prod. 79, 2158-2166. https://doi.org/10.1021/acs.jnatprod.6b00011.

Chinsembu, K., Negumbo, J., Likando, M., Mbangu, A., 2014. An ethnobotanical study of medicinal plants used to treat livestock diseases in Onayena and Katima Mulilo, Namibia. South Afr. J. Bot. 94, 101-107. https://doi.org/10.1016/j.sajb.2014.06. 007.

Del Prete, A., Scalera, A., Iadevaia, M.D., Miranda, A., Zulli, C., Gaeta, L., Tuccillo, C., Federico, A., Loguercio, C., 2012. Herbal products: benefits, limits, and applications in chronic liver disease. Evid. base Compl. Alternative Med. 2012, 1-19. https://doi. org/10.1155/2012/837939.

Diep, C.S., Baranowski, J., Baranowski, T., 2015. The impact of fruit and vegetable intake on weight management. In: Gill, T. (Ed.), Managing and Preventing Obesity, Woodhead Publishing Series in Food Science, Technology and Nutrition. Woodhead Publishing, pp. 59-78. https://doi.org/10.1533/9781782420996.2.59.

Du Preez, C.I., 2012. Evaluation of Antimalarial Properties of Indigenous Plants Used by Traditional Healers in Namibia (Thesis). University of Namibia, Windhoek, Namibia.

Du Preez, C.I., Nepolo, E., Siyengwa, R., Martin, S., Cheikhyoussef, A., Mumbengegwi, D. 2011. Study on Indigenous Medicinal Knowledge in Caprivi Region: Field Report. Multidisciplinary Research Centre, University of Namibia, Windhoek.

Feng, T., Cai, X.-H., Du, Z.-Z., Luo, X.-D., 2008. Iridoids from the bark of Alstonia scholaris. Helv. Chim. Acta 91, 2247-2251. https://doi.org/10.1002/hlca.200890244.

Geng, C.-A., Liu, X.-K., 2013. Five new indole alkaloids from the leaves of Rauvolfia yunnanensis. Fitoterapia 89, 42-47. https://doi.org/10.1016/j.fitote.2013.05.017.

Ghasemian, M., Owlia, S., Owlia, M.B., 2016. Review of anti-Inflammatory herbal medicines. Adv. Pharmacol. Sci. 2016, 1-11. https://doi.org/10.1155/2016/9130979.

Gratton, S.B., Imboden, J.B., 2010. A 23-year-old woman with fever, rash, and arthritis Arthritis Care Res. 62, 1507-1512. https://doi.org/10.1002/acr.20239.

Grubben, G.J.H. (Ed.), 2004. Vegetables. PROTA Foundation/Backhuys Publiishers, Wageningen, Netherlands.

Hassan, M., Umar, M., Ding, W., Mehryar, E., Zhao, C., 2017. Methane enhancement through co-digestion of chicken manure and oxidative cleaved wheat straw: stability performance and kinetic modeling perspectives. Energy 141, 2314-2320. https://doi. org/10.1016/j.energy.2017.11.110.

Henderson, S.C., Kamdar, M.M., Bamezai, A., 2012. Ly-6A.2 expression regulates antigenspecific CD4 + T cell proliferation and cytokine production. J. Immunol. 168, 118-126. https://doi.org/10.4049/jimmunol.168.1.118.

Hoyer, K.K., Dooms, H., Barron, L., Abbas, A.K., 2008. Interleukin-2 in the development and control of inflammatory disease. Immunol. Rev. 226, 19-28. https://doi.org/10. 1111/j.1600-065X.2008.00697.x.

Huang, Y., Xiao, D., Burton-Freeman, B.M., Edirisinghe, I., 2016. Chemical changes of bioactive phytochemicals during thermal processing. In: Reference Module in Food Science. Elsevier. https://doi.org/10.1016/B978-0-08-100596-5.03055-9.

Hylands, P.J., Magd, M.S., 1986. Cucurbitacins from Acanthocyos horridus. Phytochemistry 25 (7), 1681-1684 25, 1681-1684.

Jiang, Y., Peng, X.-R., Yu, M.-Y., Wan, L.-S., Zhu, G.-L., Zhao, G.-T., Zhou, L., Qiu, M.-H., Liu, J., 2016. Cucurbitane-type triterpenoids from the aerial parts of Momordica charantia L. Phytochem. Lett. 16, 164-168. https://doi.org/10.1016/j.phytol.2016. 04.007.

Kaushik, U., Aeri, V., Mir, S.R., 2015. Cucurbitacins - an insight into medicinal leads from nature. Phcog. Rev. 9, 12-18. https://doi.org/10.4103/0973-7847.156314.

Kitajima, M., Anbe, M., Kogure, N., Wongseripipatana, S., Takayama, H., 2014. Indole alkaloids from Kopsia jasminiflora. Tetrahedron 47, 9099-9106. https://doi.org/10. 1016/j.tet.2014.10.002.

Ko, S.-G., Yin, C.S., Du, B., Kim, K., 2014. Herbal medicines for inflammatory diseases. Mediat. Inflamm. 2014, 1. https://doi.org/10.1155/2014/982635.

Komissarenko, N.F., Chernobai, V.T., Komissarenko, A.N., 1995. New cardenolides from the leaves of Gomphocarpus fruticosus. Chem. Nat. Compd. 31, 694-700. https://doi. org/10.1007/BF01386182.

Kumar, N., Singh, B., Bhandari, P., Gupta, A.P., Kaul, V.K., 2007. Steroidal alkaloids from Holarrhena antidysenterica (L.) WALL. Chem. Pharmaceut. Bull. 55, 912-914. https:// doi.org/10.1248/cpb.55.912.

Kumar, P., 2019. Role of food and nutrition in cancer. In: Singh, R.B., Watson, R.R. Takahashi, T. (Eds.), The Role of Functional Food Security in Global Health. Academic Press, pp. 193-203. https://doi.org/10.1016/B978-0-12-813148-0. 00012-8.

Kunle, O.F., Egharevba, H.O., Ahmadu, P.O, 2012. Standardization of herbal medicines - a review. Int. J. Biodivers. Conserv. 4, 101-112. https://doi.org/10.5897/IJBC11.163.

Li, M., Hou, X.-F., Zhang, J., Wang, S.-C., Fu, Q., He, L.-C., 2011. Applications of HPLC/ MS in the analysis of traditional Chinese medicines. Journal of Pharmaceutical Analysis 1, 81-91. https://doi.org/10.1016/S2095-1779(11)70015-6.

Liu, Z., 2008. Preparation of botanical samples for biomedical research. Endocr. Metab. Immune Disord. - Drug Targets 8, 112-121.

Lull, C., Wichers, H.J., Savelkoul, H.F.J., 2005. Antiinflammatory and immunomodulating properties of fungal metabolites. Mediat. Inflamm. 2005, 63-80. https://doi.org/10.1155/MI.2005.63.

Maguraushe, K.A., 2017. Phytochemical Analysis, Radical Scavenging and Anti-microbial Activity of the Leaves of Gomphocarpus fruticosus. Thesis. University of Namibia, Windhoek, Namibia.

Mazzone, A., Cusa, C., Mazzucchelli, I., Vezzoli, M., Ottini, E., Pacifici, R., Zuccaro, P., 
Falcone, C., 2001. Increased production of inflammatory cytokines in patients with silent myocardial ischemia. J. Am. Coll. Cardiol. 38, 1895-1901. https://doi.org/10. 1016/S0735-1097(01)01660-6.

Ndhlala, A.R., Finnie, J.F., Van Staden, J., 2011. Plant composition, pharmacological properties and mutagenic evaluation of a commercial Zulu herbal mixture: imbiza ephuzwato. J. Ethnopharmacol. 133, 663-674. https://doi.org/10.1016/j.jep.2010. 10.053.

Oguntibeju, O.O., 2018. Medicinal plants with anti-inflammatory activities from selected countries and regions of Africa. J. Inflamm. Res. 11, 307-317. https://doi.org/10. 2147/JIR.S167789.

Oliveira, D.R., Leitão, G.G., Coelho, T.S., da Silva, P.E.A., Lourenço, M.C.S., Leitão, S.G., 2011. Ethnopharmacological versus random plant selection methods for the evaluation of the antimycobacterial activity. Revista Brasileira de Farmacognosia 21, 793-806. https://doi.org/10.1590/S0102-695X2011005000084.

Ozioma, E.-O.J., Chinwe, O.A.N., 2019. Herbal medicines in african traditional medicine. In: In: Builders, P.F. (Ed.), Herbal Medicine IntecOpen, London, UK, pp. 191-214.

Pahwa, R., Jialal, I., Singh, A., 2019. Chronic inflammation. In: StatPearls. StatPearls Publishing, Treasure Island (FL).

Pandey, A., Tripathi, S.M., 2014. Concept of standardization, extraction and pre phytochemical screening strategies for herbal drug. J. Pharmacogn. Phytochem. 2 , 115-119.

Rivera, J.O., Loya, A.M., Ceballos, R., 2013. Use of herbal medicines and implications for conventional drug therapy medical sciences. Alternat. Integr. Med. 2, 1-6. https:// doi.org/10.4172/2327-5162.1000130.

Roy, M.C., Chang, F.-R., Huang, H.-C., Chiang, M.Y.-N., Wu, Y.-C., 2005. Cytotoxic principles from the formosan milkweed, Asclepias curassavica. J. Nat. Prod. 68, 1494-1499. https://doi.org/10.1021/np0501740.

Saidu, A.N., Alejolowo, O.O., Kuta, F.A., 2014. Antibacterial effect and phytochemical screening of selected medicinal plants. World J. Pharmaceut. Sci. 3, 84-92.

Sasidharan, S., Chen, Y., Saravanan, D., Sundram, K.M., Yoga Latha, L., 2010. Extraction, isolation and characterization of bioactive compounds from plants' extracts. Afr. J. Tradit., Complementary Altern. Med. 8, 1-10.

Schmelzer, G., Gurib-Fakim, A., Arroo, R., Bosch, C.H., de, Ruijter, Simmonds, M.,
Lemmens, R.H.M.J., Oyen, L.P.A., 2013. Plant Resources of Tropical Africa 11(1): Medicinal Plants 1. PROTA Foundation, Wageningen, Netherlands.

Silva, A.C.O., Santana, E.F., Saraiva, A.M., Coutinho, F.N., Castro, R.H.A., Pisciottano, M.N.C., Amorim, E.L.C., Albuquerque, U.P., 2013. Which approach is more effective in the selection of plants with antimicrobial activity? Evid. base Compl. Alternative Med. 2013, 1-9. https://doi.org/10.1155/2013/308980.

Sonoda, K., Tanaka, Y., Tokuda, Y., 2017. A young man with multiple joint pains and fever: a case with the importance of accurate history taking. J. General Family Med. 18, 79-81. https://doi.org/10.1002/jgf2.21.

Steiger, J., Whalen, A., Staunton, J., Wilson, A., Wu, Y., 2011. Methods and Compositions for Treatment of NF-kB-Mediated and Alpha-7 Integrin-Suppressed Diseases.

Stuurmann, H.A., 2016. An Investigation of the in Vitro Anti-cancer Properties of Acanthosicyos naudinianus Fockea angustifolia, Cf Salvadora Persia and Nymania capensis from Hardap and//Karas Regions of Namibia. Thesis. University of Namibia.

Thirumal, Y., Laavu, S., 2017. HPLC profile of medicinal plant extracts and its application in aquaculture. J. Aquacult. Res. Dev. 8, 1-4. https://doi.org/10.4172/2155-9546. 1000484.

Trejo, S.A., López, L.M.I., Caffini, N.O., Natalucci, C.L., Canals, F., Avilés, F.X., 2009. Sequencing and characterization of asclepain f: the first cysteine peptidase cDNA cloned and expressed from Asclepias fruticosa latex. Planta 230, 319-328. https://doi org/10.1007/s00425-009-0942-2.

Twilley, D., Langhansová, L., Palaniswamy, D., Lall, N., 2017. Evaluation of traditionally used medicinal plants for anticancer, antioxidant, anti-inflammatory and anti-viral (HPV-1) activity. South Afr. J. Bot. 112, 494-500. https://doi.org/10.1016/j.sajb. 2017.05.021.

Von Koenen, E., 2007. Medicinal, Poisonous, and Edible Plants in Namibia, Edition Namibia. Klaus Hess Publishers, Göttingen, Germany.

Zhang, J., Huang, Y., Kikuchi, T., Tokuda, H., Suzuki, N., Inafuku, K., Miura, M., Motohashi, S., Suzuki, T., Akihisa, T., 2012. Cucurbitane triterpenoids from the leaves of Momordica charantia, and their cancer chemopreventive effects and cytotoxicities. Chem. Biodivers. 9, 428-440. https://doi.org/10.1002/cbdv.201100142.

Zhang, J.-M., An, J., 2007. Cytokines, inflammation and pain. Int. Anesthesiol. Clin. 45, 27-37. https://doi.org/10.1097/AIA.0b013e318034194e. 